\title{
Forecasts an employment rate of older workers in Poland with time - area analogy method
}

Ph.D. Eng. Anna Gondek University of Zielona Gora Faculty of Economics and Management

\section{Introduction}

Polish accesion to European Union (EU) was an inspiration to comparing economical situation of countries. Many politicans and economists ask about a range of delay of polish economy in comparison to any UE countries, they ask about suitable pase of catching up average strong economic countries, what is associated with level of employment.

The aim of the paper is firstly a comparative analysis the employment rate of older workers in Poland and any different UE countries with using time - area analogies method, which unable to find countries similar to Poland in terms of the rate of employment of older workers and evaluate of range of delay of this rate in comparison to any EU countries and secondly the construction of forecasts of this rate in Poland for the next few years. Now, employment rate of older workers belongs to the most important rates from labour market and unemployment in this age category becames social, economical, political, demographic, psychological and socjological problem. Interested experts from these fields can be addressees of the examination, in particular economists and politicians dealing 
with the economic policy. For the social- economic development of Poland these issues are crucial also because at present in Poland the employment rate of older workers belongs to lowest in the EU.

\section{Time - area analogy method}

The method of time - area analogies is based on the transfer of the regularity in one variable in time into different variables in a different object (Dittmann 2004, p. 146, Prognozowanie ... 2004, p. 149). Usually, there are one-named variables here. A forecaster is using active approach in this method. The time - area analogies are useful for forecasting of demand for goods and services which are premium, and for the forecasting of their production, as well (Prognozowanie ... 2004, p. 149). Moreover, this method is very useful for the demographic (Gondek 2009, 2011), macroeconomic (Gondek 2008, 2010) and in national safety area (Dalecka, Gondek 2010) forecasting.

\section{Forecasting employment rate of older workers in Poland}

A phenomenon of the employment rate of older workers was analysed in the EU. For that purpose an available statistical data was collected from 1991 to 2011 describing this phenomenon as an average value of this indicator in the EU ( fig. 1).

Since 1991 to 1996 in the examined phenomenon on average there was a decreasing tendency in the EU. Since the next year to this day a slow growth of this indicator takes place. It is associated with the ageing process of societies the EU at simultaneous applying incentives both towards older persons as well as towards entrepreneurs for employing olderly people. In the last examined year i.e. in 2011 the mean of this indicator in the EU amounted to the $46.8 \%$. How in these years did the value of this indicator develop in Poland? Fig. 2 presents the employment rate of older workers since 1997 to 2011 in Poland (priorer data describing this phenomenon in Poland does not exist).

Since 1997 to 2002 the examined phenomenon had the decreasing trend, the low level of the employment rate of older workers in Poland was in 2002 and amounted to the $26.1 \%$. A slow growth is taking place since this year and in 2011 in Poland the employment rate of older workers amounted to $36.9 \%$. It is about almost a $10 \%$ fewer than on average in the EU. An ageing societies in the EU employ more of old workers, because a number of such workers grows on the labour market, morover the EU countries conduct the active policy of employing

Forecasts an employment rate of older workers in Poland with time - area analogy 


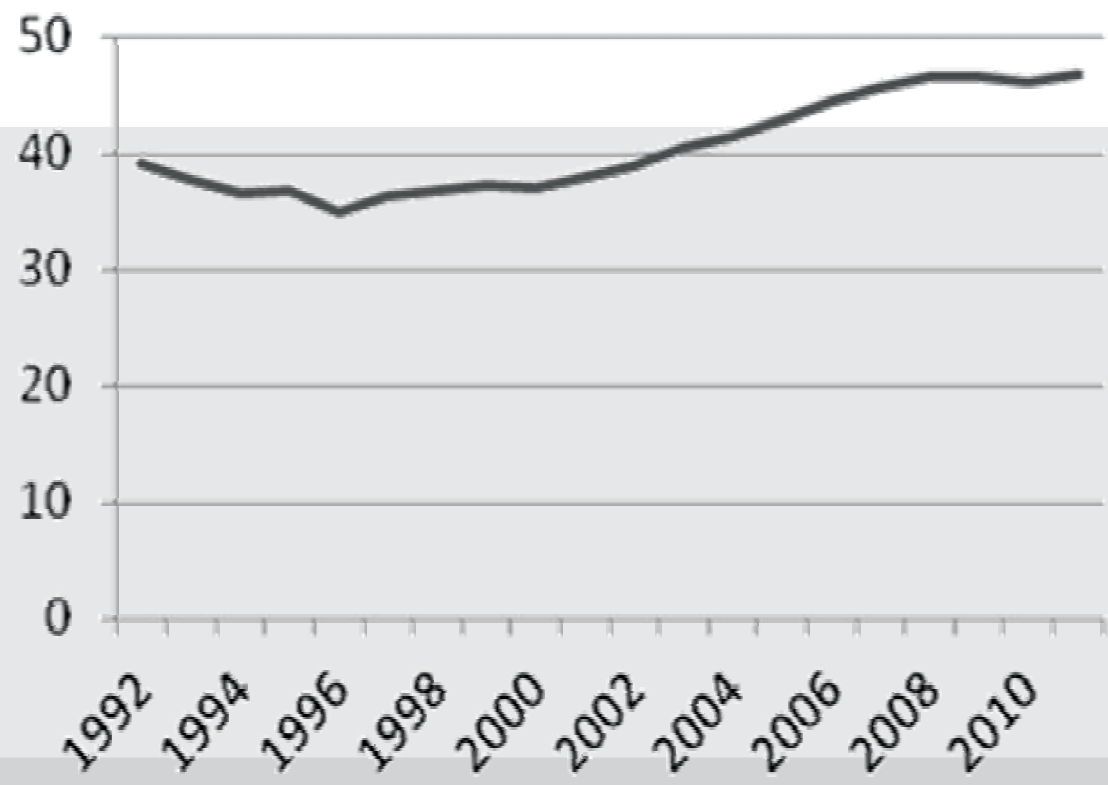

Figure 1. Employment rate of older workers in EU in 1991-2011

Source: own elaboration based on Eurostat data

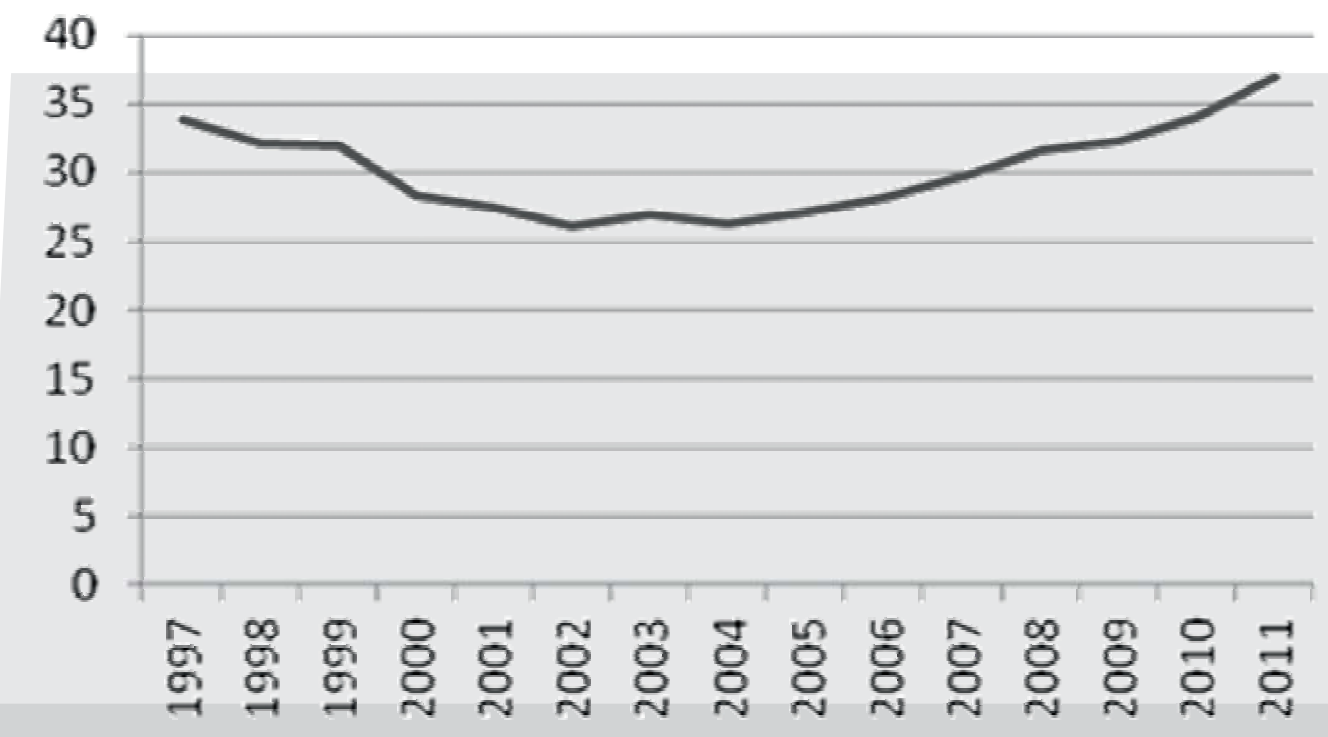

Figure 2. Employment rate of older workers in EU in 1997-2011

Source: own elaboration based on Eurostat data 
such persons. Imitative tendencies occurring in demographic phenomena encourage to predictions, that the Polish labour market and its components will develop as similarly as in the EU. Therefore amongst EU countries the authors looked for the ones which are most similar to Poland in terms of the examined phenomenon.

Forecasting based on time - area analogies consists of some stages (Dittmann 2004, p. 147, Prognozowanie ... 2004, p. 150):

1. Choice of homothetic objects $(k)$. In the research the author looked for analogies between employment rate of older workers in Poland and in the different EU countries. The employment rate in such countries like Poland, Austria, Bulgaria, Belgium, Cyprus, Czech Republic, Denmark, Estonia, Finland, France, Germany, Greece, Hungary, Ireland, Italy, Luxembourg, Lithuania, Latvia, Malta, Netherlands, Portugal, Romania, Slovenia, Slovak Republic, Spain, Sweden and United Kingdom (27) were analysed. It is neceşsary to begin from the assumption of border value of the similarity measure $m$ (in this research $m=0,6$ ) and additionally correlation coefficient $r=0,7$, and choose the homothetic objects, that are similar to the researched object. Countries like Austria, Belgium, Czech Republic, Denmark, Estonia, Finland, France, Germany, Hungary, Ireland, Italy, Luxembourg, Lithuania, Netherlands, Portugal, Romania, Slovenia, Slovak Republic, Spain, Sweden and United Kingdom, (21) were supposed to have analogies in employment rate with Polish employment rate. Moreover, the countries where the inspected indicator is lower than in Poland were excluded from the group of these countries, because it attests that Poland achieves better results in this area, and so it is not possible to talk about the imitative tendency, because rather these countries imitate Poland. For this reason researcher removed from the set of explored countries: Belgium, Italy, Luxembourg, Hungary, Slovenia, Slovakia. On the whole length of time series characterizing the homothetic objects it is urgent to find the intervals of similarity that they are the same length (in this research the length of the interval is equal eight years) and their similarity meaşure $m^{(o, k)}$ is not less than critical (established previously) similarity measure $m$. Then we should choose such pairs among them in order to measure of similarity between them achieves maximum value. The qualification of the grade of similarity changes of variable value in the interval of similarity to changes in homothetic objects is suitable to apply (Dittmann 2004, p. 147, Prognozowanie... 2004, p. 142):

a) the coefficient of linear correlation; in order to decide about the correlation, an above scale should be used: if $r_{X Y}=0$, there is no correlation; if $0<r_{X Y}<0,1$, there is lower correlation; if $0,1 \leq_{X Y}<0,3$, there is low correlation; if $0,3 \leq \mathrm{r}_{X Y}<0,5$,

Forecasts an employment rate of older workers in Poland with time - area analogy 
there is avarage correlation; if $0,5 \leq r_{X Y}<0,7$, there is high correlation; if $0,7 \leq r_{X Y}$ $<0,9$, there is very high correlation; if $0,9 \leq \mathrm{r}_{X Y}<1$, there is almost full correlation; if $r_{X Y}=1$, then there is linear dependency between variables (Szmigiel, Mercik 2000, p.21) .

b) the similarity measure of function $m$ (Nieklasyczne ... 1983, p. 107); in order to achieve it, it is urgent to consider a function $f: \mathrm{y}^{(0)}=[\mathrm{a} ; \mathrm{b}]$ and $g: \mathrm{y}^{(\mathrm{k})}=[\mathrm{c} ; \mathrm{d}]$, but b-a $=\mathrm{d}-\mathrm{c}$. Compartments $\mathrm{y}^{(0)}, \mathrm{y}^{(\mathrm{k})}$ should be divided in a way:

$$
\begin{gathered}
a=a_{1}, a_{2}, \ldots, a_{n+1}=b, \\
c=c_{1}, c_{2}, \ldots, c_{n+1}=d .
\end{gathered}
$$

The measure of analogy for functions $f$ and $g$ in $[a ; b],[c ; d]$ for $a_{1^{\prime}}, a_{2^{\prime}} a_{n+1} ; c_{1^{\prime}}, c_{2^{\prime}}$ $\mathrm{c}_{\mathrm{n}+1}$ is

$$
m=\frac{1}{n} \sum_{i=1}^{n} m_{i}, \quad \text { but }-1<\mathrm{m} \leq 1,
$$

where:

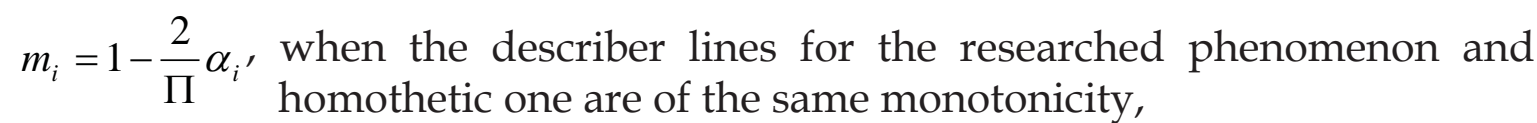
$m_{i}=\frac{\alpha_{i}}{\Pi}, \quad \begin{aligned} & \text { when the describer lines for the researched phenomenon and } \\ & \text { homothetic one are of different monotonicity, }\end{aligned}$

$n \quad$ is the number of observation for the variable as well as the variable homothetic to it in compartments of similarity, and $\alpha_{i}$ the arc measure of contained angle between two straight lines that should be counted with the following formula:

$$
\cos \alpha_{i}=\frac{\left(a_{i+1}-a_{i}\right)\left(c_{i+1}-c_{i}\right)+\left[f\left(a_{i+1}\right)-f\left(a_{i}\right)\right]\left[g\left(c_{i+1}\right)-g\left(c_{i}\right)\right]}{\sqrt{\left(a_{i+1}-a_{i}\right)^{2}+\left[f\left(a_{i+1}\right)-f\left(a_{i}\right)\right]^{2}} * \sqrt{\left(c_{i+1}-c_{i}\right)^{2}+\left[g\left(c_{i+1}\right)-g\left(c_{i}\right)\right]^{2}}}
$$

and then the values of angles should be read from boards or find with usage Arcuscosinus. It is self evident that with regard to the use of the time series above mentioned formula will undergo considerable reduction: 


$$
\cos \alpha_{i}=\frac{1+\left[f\left(a_{i+1}\right)-f\left(a_{i}\right)\right]\left[g\left(c_{i+1}\right)-g\left(c_{i}\right)\right]}{\sqrt{1+\left[f\left(a_{i+1}\right)-f\left(a_{i}\right)\right]^{2}} * \sqrt{1+\left[g\left(c_{i+1}\right)-g\left(c_{i}\right)\right]^{2}}}
$$

where $a_{i}, c_{i}$ are the numbers of observation $f\left(a_{i}\right), g\left(c_{i}\right)$.

For analysis the researcher took eight last years for Poland i.e. 2004 - 2011. At this stage analogies between Poland and such countries as: Belgium, Denmark, Germany, Estonia, Ireland, France, Netherlands, Portugal, Sweden, Great Britain, Finland were confirmed. Results were placed in table 1, countries which results excluded them from further research were indicated with bold letter.

Table 1. Similarity intervals, correlation coefficient $r$ and similarity measure of function $m$ for the research of employment rate of older workers

\begin{tabular}{|c|c|c|c|c|}
\hline number & country & Similarity intervals & $\begin{array}{l}\text { correlation } \\
\text { coefficient } r\end{array}$ & $\begin{array}{c}\text { and similarity } \\
\text { measure of function } \\
m\end{array}$ \\
\hline 1 & Belgium & $2000-2007$ & 0,97 & 0,63 \\
\hline 2 & Czech Republic & 1998-2005 & 0,94 & 0,59 \\
\hline 3 & Denmark & 1996-2003 & 0,97 & 0,63 \\
\hline 4 & Germany & 2001-2008 & 0,99 & 0,89 \\
\hline 5 & Estonia & 1999-2006 & 0,98 & 0,6 \\
\hline 6 & Ireland & 1999-2006 & 0,99 & 0,87 \\
\hline 7 & Spain & 1994-2001 & 0,98 & 0,57 \\
\hline 8 & France & $1997-2004$ & 0,95 & 0,63 \\
\hline 9 & Lithuania & 2000-2007 & 0,98 & 0,59 \\
\hline 10 & Netherlands & $1993-2000$ & 0,98 & 0,69 \\
\hline 11 & Portugal & 1993-2000 & 0,96 & 0,62 \\
\hline 12 & Austria & $2000-2007$ & 0,89 & 0,56 \\
\hline 13 & Romania & 2002-2009 & 0,92 & 0,32 \\
\hline 14 & Sweden & 1997-2004 & 0,97 & 0,8 \\
\hline 15 & United Kingdom & 1997-2004 & 0,99 & 0,86 \\
\hline 16 & Finland & 2001-2008 & 0,97 & 0,81 \\
\hline
\end{tabular}

Source: own study 
The coefficient of correlation points at very high correlation between the range for Poland and with ranges of selected countries. The measure of similarity of the function is bigger than the critical value in 11 cases out of 16 and these countries went to next research stages.

2. Counting shift constant $\Delta^{(o, k)}$. Before calculation the partial forecasts, shift constant ought to be established: $\Delta^{(0, k)}=y_{0}(0)-y(k)$, where $y_{0}(0)$ is a value in the end of the compartment of similarity for the forecasted object, and $y_{0}(k)$ is a value in the end of the compartment of similarity for the homothetic object $k$. In the research the shift constant should be negatjye.

3. Calculation of the partial forecasts $y_{t}{ }^{(0, k)}$. Values for the numbers of periods from $t=1$ in time series for the homothetic objects will be used for partial forecasts:

$y_{t}^{*}(o, k)=y_{t}(k)+\Delta(o, k), \quad t=1, \ldots, n(k)$

where the $y_{t}{ }^{*}(0, k)$ is the partial forecast for variable $Y$ for object $(o)$ in the moment $t$ according to object $(k), y_{t}{ }^{(k)}$ is the yalue of variable $Y$ in $k$ object in the moment $t$, $\Delta^{(0, k)}$ the forecast shift constant, $n^{(k)}$ - the length of the similarity compartment. Because shift constant in case of Belgium is positive, this country was removed from further research (it was assumed that a growth of this indicator will happen in Poland and Poland will imitate these countries, where this indicator is higher than in Poland).

Table 2. Shift constant $\Delta$, partial forecasts for the research of employment rate of older workers

\begin{tabular}{c|c|c|c|c|c|c}
\hline \multirow{2}{*}{ 1.p. } & \multirow{2}{*}{ country } & Shift constant & \multicolumn{4}{|c}{ Partial forecasts } \\
\cline { 3 - 7 } & & $\Delta$ & $\mathbf{2 0 1 2}$ & $\mathbf{2 0 1 3}$ & $\mathbf{2 0 1 4}$ & $\mathbf{2}$ \\
$\mathbf{t = 1}$ & $\mathbf{t}=\mathbf{2}$ & $\mathbf{t}$ & $\mathbf{t}=\mathbf{4}$ \\
\hline 1 & Belgium & 2,5 & n.d. & n.d. & n.d. & n.d. \\
\hline 2 & Denmark & $-23,3$ & 37 & 36,2 & 37,4 & 35,6 \\
\hline 3 & Gemany & $-16,8$ & 39,3 & 40,9 & 43,1 & n.d. \\
\hline 4 & Estonia & $-21,6$ & 38,4 & 40,8 & 38,8 & 32,2 \\
\hline 5 & Ireland & $-16,2$ & 37,6 & 37,5 & 35,1 & 34 \\
\hline 6 & France & $-0,9$ & 37,6 & 37,2 & 37,3 & 37,3 \\
\hline 7 & Netherland & $-1,3$ & 38,3 & 41 & 43 & 43,9 \\
\hline
\end{tabular}




\begin{tabular}{c|c|c|c|r|r|r}
\hline 8 & Portugal & $-13,8$ & 36,4 & 37,6 & 37,8 & 36,5 \\
\hline 9 & Sweden & $-32,2$ & 37,2 & 37,4 & 37,8 & 37,9 \\
\hline 10 & United Kingdom & $-19,3$ & 36,9 & 37,5 & 38 & 38,1 \\
\hline 11 & Finland & $-19,6$ & 35,9 & 36,6 & 37,4 & n.d. \\
\hline
\end{tabular}

Source: own study

Note: n.d. - no data, $t$ - period of time

Next moving time series was made (table 3).

Table 3. Leveled time series for employment rate of older workers in Poland and chosen UE countries

\begin{tabular}{|c|c|c|c|c|c|c|c|c|c|c|}
\hline \multirow{2}{*}{ no. } & \multirow{2}{*}{ country } & \multicolumn{9}{|c|}{ data for forecasting periods } \\
\hline & & 0 & 1 & 2 & 3 & 4 & 5 & 6 & 7 & 8 \\
\hline 1 & Denmark & 60,2 & 60,3 & 59,5 & 60,7 & 58,9 & 58,4 & 58,2 & 58,4 & 59,5 \\
\hline 2 & Gemany & 53,7 & 56,1 & 57,7 & 59,9 & n.d. & n.d. & n.d. & n.d. & n.d. \\
\hline 3 & Estonia & 58,5 & 60 & 62,4 & 60,4 & 53,8 & 57,2 & n.d. & n.d. & n.d. \\
\hline 4 & Ireland & 53,1 & 53,8 & 53,7 & 51,3 & 50,2 & 50 & n.d. & n.d. & n.d. \\
\hline 5 & France & 37,8 & 38,5 & 38,1 & 38,2 & 38,2 & 39 & 39,8 & 41,5 & n.d. \\
\hline 6 & Netherland & 38,2 & 39,6 & 42,3 & 44,3 & 45,2 & 46,1 & 47,7 & 50,9 & 53 \\
\hline 7 & Portugal & 50,7 & 50,2 & 51,4 & 51,6 & 50,3 & 50,5 & 50,1 & 50,9 & 50,8 \\
\hline 8 & Sweden & 69,1 & 69,4 & 69,6 & 70 & 70,1 & 70 & 70,5 & 72,3 & n.d. \\
\hline 9 & $\begin{array}{l}\text { United } \\
\text { Kingdom }\end{array}$ & 56,2 & 56,8 & 57,3 & 57,4 & 58 & 57,5 & 57,1 & 56,7 & n.d. \\
\hline 10 & Finland & 56,5 & 55,5 & 56,2 & 57 & n.d. & n.d. & n.d. & n.d. & n.d. \\
\hline
\end{tabular}

Source: own study

Note: n.d. - no data

4. Calculation of the global forecast $y_{t}{ }^{*}$. The global forecast for the research object made on the ground of the similarity of the shape to the variable in the different objects should be prepared according to the following formula: 
$y_{t}^{*(0)}=\sum_{k=1}^{K} y_{i}^{*(o, k)} w^{(o, k)}$, where $w^{(o, k)}=\frac{m^{(0, k)}}{\sum_{k=1}^{K} m^{(0, k)}}$

a $\mathrm{K}$ is the number of the explanatory variables. The global forecast for a period $t$ will be made as the extrapolation of the time series for researched variable beyond the compartment of similarity for this variable $P^{(0)}$ by adding the average value of the partial forecast for this term. After calculation, the global forecasts for employment rate of older workers in Poland for 2012 to 2015 were achieved (table 4 ) and presented in fig. 3.

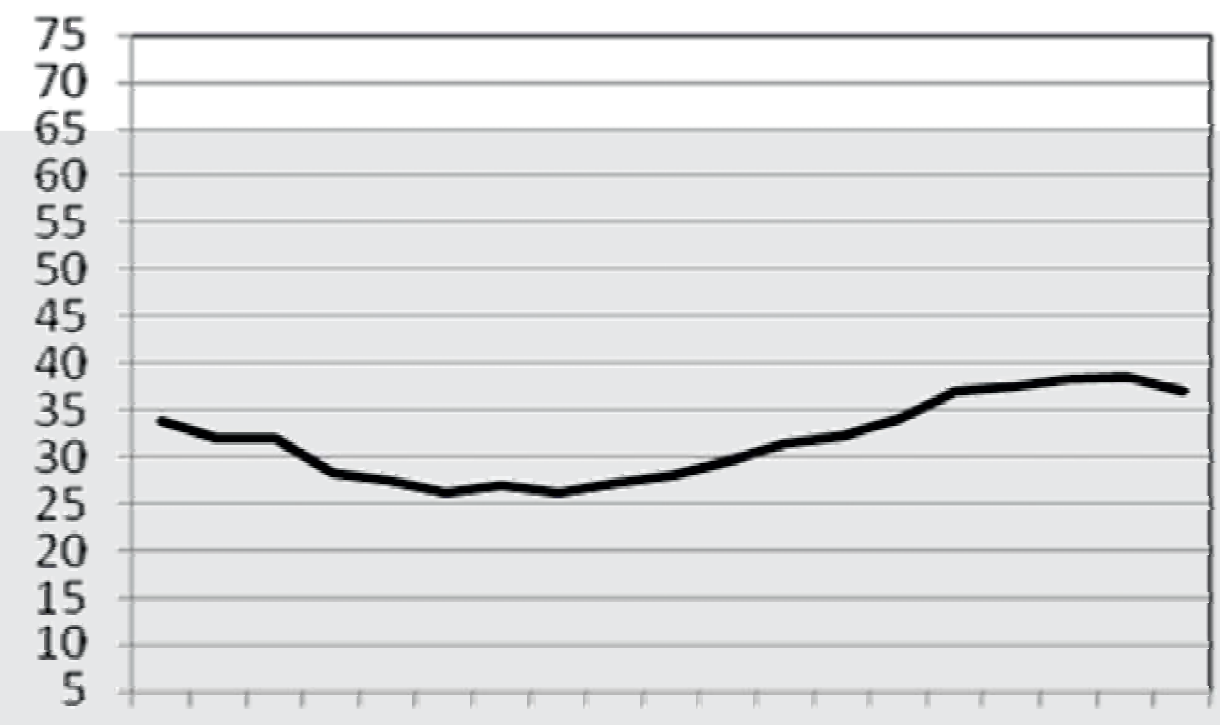

1997199920012003200520072009201120132015

Figure 3. Employment rate of older workers in Poland in 1997 - 2011 and forecasts for 2012 - 2015

Source: own study

Credibility of obtained forecasts with method of the time - area analogy is determined on the basis of the number of similar objects, measures of similarity and length of similarity ranges. In this research the forecast are credible, because they are based on similarity to ten countries, ranges of similarity are eight-year that is are very long and a critical level of the measure of similarity $\mathrm{m}^{*}$ was 
reached (in fact $m=0.6$ is relatively low, but in case of every of explored country in chosen periods, there is very high correlation which compensates not too high values of the measure of similarity).

Table 4. Global forecasts for employment rate of older workers in Poland for 2012 - 2015

\begin{tabular}{c|c}
\hline Year & Global forecasts \\
\hline 2012 & 37,47 \\
\hline 2013 & 38,26 \\
\hline 2014 & 38,58 \\
\hline 2015 & 36,9 \\
\hline
\end{tabular}

Source: own study

\section{Results}

According to the global forecasts of the employment rate of older workers in Poland, it will achieve almost a 37.5\% in 2012, and in 2013 38.26\%, in 2014 almost a $38.6 \%$, and then in 2015 will slight decline up to almost a 37\%. It is necessary to remember, that the further horizons of the forecast, the improbability is bigger, hence attitude to this forecast for 2015 should careful particularly that an increasing trend appears in the examined phenomenon in the EU.

Similarity the employment rate of older workers in Poland and some countries (in earlier periods than last eight years) was noticed and arithmetically confirmed. These countries are: Denmark, Germany, Estonia, Ireland, France, Netherlands, Portugal, Sweden, Great Britain and Finland. These countries have contended with the problem of getting older of workers for a dozen or so years and simultaneously the labour markets in these countries are regarded elastic.

In Poland the problem of the ageing of workers is a relatively young and that is why concepts of managing with this process, as well as methods of the increasing of employment of people over 50 , are in the early phase, and the straight extrapolation of experience of other countries in this respect can be ineffective and even harmful - it is necessary to create own methods taking the reality of the Polish labour market into account and social - economic conditions. 
Elasticity of the labour market, which was mentioned above, is the second important aspect which considers both employees and employers. In the elastic labour market entrepreneurs willingly employ workers, because they know that they can dismiss the employee easily, when is not needed, but also willingly create new jobs exactly on account of the easiness of dismissing employees, whereas workers accommodating themselves to needs of companies, they can be reduced easily, if the company does not need them, but also quickly they find a job.

So the flexibility means the easiness of taking employing, as well as dismissing. The larger it is, the greater freedom of employing and reducing are and the smaller interference in pays is (on the elastic labour market a wage increase is adapted to the intensification of productivity). Institutions of the employment exchange which help to find employment perform the substantial role in increasing the elasticity of the labour marketAnd so the flexibility depends on the structure of the labour market, education level of employees, institutional arrangements and the economic policy. It is measured with the statutory elasticity of the work, with existence of the minimum wage and rather its relation to the average wage expressed in the per cent, with indicator of employees have a part-time job and for the limited duration and with the level of membership in trade unions. Attitude to this measures should be cautious, because for example the high level of term contracts in Poland does not attest to the elasticity of the labour market (as this way as in well-developed economies), but attests to the low safety of workers and abuses of employers towards employees.

The particular attention is devoted to the minimum wage which exists in the majority of EU countries, it does not exist only in Sweden, Denmark, Austria, Italy and on Cyprus, and in Germany hourly rates are set for industries. Rates of the minimum wage to the average wage in EU countries fluctuate from the 35\% to the $50 \%$ in the case of Greece and Slovenia, in the majority of countries the EU it fluctuates around the $40 \%$. In Poland it amounts below to the $40 \%$ and it seems that assigning to it the role of the special brake on the road to the elastic labour market is unjustified.

It should be noticed that in $90^{\text {th }}$ the United States and Great Britain had the more elastic labour markets than Euromarkets. In the last decade an increase in the flexibility of labour markets has taken place in EU countries what resulted in the increase of the indicator of employing older workers. Germany was a special success in this regard (in 2003 the indicator of employing of older workers equals 33.9, and in 2011 59.9) thanks to the package of Hartz's four acts which liberalized the labour market and enabled wider containing fixed term contracts with old 
hands, moreover an allowance of the remuneration of older people and reduction in amounts of contributions for the unemployment insurance were introduced. Similarly in Netherlands (since 1996 a rate of the employment of older workers has rised, now it is 56.1), where as a result of reforms they reduced of granting disability pensions as well as tax advantageous solutions were eliminated for persons resigning from the labour market below the statutory retirement age, and in addition all systems enabling to take early retirement were liquidated. At present in Netherlands reducing non-pay labour costs for employees 62 is moving in for sixty-two years old workers.

Polish labour market is regarded stiff. But in the last years in Poland companies not only do not dismiss people above 50., but employ them. The height of employment rate of older workers in Poland should be expected what is closely associated with inevitable demographic changes, but also with such an adverse phenomenon like of the emigration abroad of young educated people (Walega 2008, p. 117). An attitude towards such employees has changed - companies have more and more invested in their development searching out in their experiencing the essential source of enterprises. Unfortunately, this process has happend slowly, what is confirmed by the gap between the value of the employment rate of older workers in the majority of the EU countries and Poland. Low job activity of people above 50 results from moderately lower professional qualifications and the incongruity to expectations of employers, changes in the matter of the organization and the labour culture, as well as manners of a job-hunt (Walega 2008, p. 117).

Appropriate programmes activating both older workers and entrepreneurs for employing older persons with experience should be implemented. Applying incentives towards employees in the form of the employment exchange and the career counselling, the organization of workshops and trainings from the scope of an active job-hunt, psychological counselling, increasing informationadvisory accessibilities of services, raising trainings or drivers for the change of professional qualifications as well as incentives towards entrepreneurs in financial character in the form of concessions in contributions for the Labour Fund and the Fund of Guaranteed Employee Benefits or subsidizing the employment and in non-financial character by the organization of promotional campaigns and information actions directed to employers especially in the Small and Medium enterprises and to employees. 


\section{Summary}

Forecasts employment rate of older workers in Poland with time - area analogy method

This article presents the research which aim was to construct forecasts of an employment rate of older workers in Poland for next few years. The time - area analogy method was use in this study and brought high credibility forecasts of the employment rate based on analogies between Poland and UE countries in research phenomenon.

Key words: employment rate of older workers, forecast.

\section{Streszczenie}

Prognozy wskaźnika zatrudnienia starszych pracowników w Polsce metodą analogii przestrzenno - czasowych

Artykuł prezentuje badanie, którego celem było skonstruowanie prognoz wskaźnika zatrudnienia starszych pracowników w Polsce na najbliższe lata. Do postawienia wiarygodnych prognoz użyto metody analogii przestrzenno - czasowych i wykorzystano analogie w kształtowaniu się badanego zjawiska miedzy Polską a krajami UE.

\section{Słowa}

kluczowe: wskaźnik zatrudnienia starszych pracowników, prognoza.

\section{References}

1. Cieślak M. (Ed.) (1983), Nieklasyczne metody prognozowania, PWN, Warszawa.

2. Cieślak M. (Ed.) (2001), Prognozowanie gospodarcze. Metody i zastosowania, PWN, Warszawa.

3. Cieślak M. (Ed.) (2004),Prognozowanie gospodarcze. Metody i zastosowania, PWN, Warszawa.

4. Dalecka M., Gondek A. (2010), The forecasts of the crime rate in Poland in the face of new economic and geopolitical circumstance, "Management" 2010, Vol. 14, No. 2, s. 200-212.

5. Dittmann P. (2004), Prognozowanie w przedsiębiorstwie. Metody $i$ ich zastosowanie, Oficyna Ekonomiczna, Kraków.

6. Gondek A. (2008), Prognozy dynamiki realnego PKB w Polsce z wykorzystaniem metody analogowej w: P. Dittman, J. Szanduła (red.), Prognozowanie w zarzadzaniu firma, Wrocław, Wyd. Indygo Zahir Media, s. 205-210. 
7. Gondek A. (2009), Prognozy przyrostu naturalnego dla Polski na tle krajów UE z użyciem metody analogii przestrzenno-czasowych - część druga, w: Wawrzyniec W., Zaborowski T. (red.), Aporie ekologii pogranicza, Zielona Góra, ZWSHiFM, s. 118-125.

8. Gondek A. (2010), Forecasts an unemployment rate in Poland with time - area analogy method, „Management” 2010, Vol. 14, No. 1, s. 288-296.

9. Gondek A. (2011), Prognozowanie rodności w Polsce metoda analogii przestrzenno-czasowych, „Wiadomości Statystyczne”, R. 56, nr 2, s. 48-59.

10. Panek T. (Ed.) (2007), Statystyka społeczna, PWE, Warszawa.

11. Radzikowska B. (Ed.) (2000), Metody prognozowania. Zbiór zadań, Wyd. Akademii Ekonomicznej w Poznaniu, Wrocław.

12. Szmigiel C., Mercik J. (2000), Ekonometria, Skrypt Wyższej Szkoły Zarządzania i Finansów we Wrocławiu, Wrocław.

13. Walega G., (2008), Aktywność ekonomiczna osób starszych, w: Dach Z. (Ed.), Rynek pracy w Polsce. Aspekty społeczno-ekonomiczne, Wydawnictwo Uniwersytetu Ekonomicznego w Krakowie, Kraków.

Forecasts an employment rate of older workers in Poland with time - area analogy 